\title{
HUBUNGAN SARAPAN PAGI DENGAN PRESTASI BELAJAR SISWA DI SMA NEGERI 4 KOTA JAMBI TAHUN 2020
}

\author{
Riska Marvelia, Rini Kartika, Hasna Dewi \\ Fakultas Kedokteran dan IImu Kesehatan Universitas Jambi \\ Corresponding author email : riskamarvellia@gmail.com
}

\begin{abstract}
Breakfast has an important role in meeting the energy needs of student, because it can increase learning concentration and make it easier to absorb lessons at school, so that learning achievement is good. The research objective was to determine the relationship between breakfast and student academic achievement levels in Senior High School 4 Jambi City in 2020. This research is an analytic survey research with cross sectional design. The population is students who sit in class X MIPA and XIIS at Senior High School 4 Jambi City in 2020. The sample of simple random sampling technique is 110 people. This research was conducted at Senior High School 4 Jambi City in July-August 2020 in 2020 by direct interviews using a questionnaire. Data were analyzed by univariate and bivariate. The results of univariate analysis showed that 34 respondents (30.9\%) had good breakfast, 43 respondents (39.1\%) were sufficient, and 33 respondents (30.0\%) were lacking. As for the description of study achievement, 59 respondents (53.6\%) were good, 45 respondents (40.9\%) were sufficient and 6 respondents (5.5\%) were less. The bivariate results showed a significant relationship between breakfast and student achievement with a $p$-value (0.014). There is a significant relationship between breakfast and student achievement. Breakfast is useful in increasing learning concentration and memory when studying at school so that it will result in better achievement
\end{abstract}

Keywords: Breakfast, study achievement

\begin{abstract}
ABSTRAK
Sarapan pagi mempunyai peranan penting dalam memenuhi kebutuhan energi anak sekolah, karena dapat meningkatkan konsentrasi belajar dan memudahkan menyerap pelajaran di sekolah, sehingga prestasi belajar menjadi baik. Tujuan penelitian untuk mengetahui hubungan sarapan pagi dengan tingkat prestasi belajar siswa di SMA Negeri 4 Kota Jambi Tahun 2020. Penelitian ini merupakan penelitian survey analitik dengan rancangan cross sectional. Populasi adalah adalah siswa yang duduk di kelas X MIPA dan X IIS di SMA Negeri 4 Kota Jambi Tahun 2020. Sampel teknik simple random sampling yang berjumlah 110 orang. Penelitian ini dilakukan di SMA Negeri 4 Kota Jambi bulan Juli-Agustus 2020 tahun 2020 dengan wawancara langsung menggunakan kuesioner. Data dianalisis secara univariat dan bivariat. Hasil analisis univariat didapatkan gambaran untuk sarapan pagi sebanyak 34 responden (30,9\%) baik, 43 responden $(39,1 \%)$ cukup, dan 33 responden $(30,0 \%)$ kurang. Sedangkan untuk gambaran prestasi belajar didapatkan sebanyak 59 responden (53,6\%) baik, 45 responden (40,9\%) cukup dan 6 responden (5,5\%) kurang. Hasil bivariat terdapat hubungan yang bermakna antara sarapan pagi dengan prestasi belajar siswa dengan $\mathrm{p}$ value $(0,014)$. Terdapat hubungan yang bermakna antara sarapan pagi dengan prestasi belajar siswa.
\end{abstract}


MEDIC, Volume 4, nomor 1, April 2021, Hal:198-205 Riska Marvelia, dkk. Hubungan sarapan...

Sarapan berguna dalam meningkatkan konsentrasi belajar dan daya ingat ketika belajar di sekolah sehingga akan menghasilkan prestasi yang lebih baik.

Kata Kunci : Sarapan pagi, Prestasi belajar

\section{PENDAHULUAN}

Sarapan pagi merupakan faktor yang mempengaruhi konsentrasi belajar anak di sekolah. Makan pagi atau sarapan pagi mempunyai peranan penting dalam memenuhi kebutuhan energi anak sekolah, karena dapat meningkatkan konsentrasi belajar dan memudahkan menyerap pelajaran di sekolah, sehingga prestasi belajar menjadi baik. Sarapan menyumbangkan energi sebesar $25 \%$ dari kebutuhan gizi sehari. Glukosa merupakan bahan bakar otak sehingga dapat membantu dalam mempertahankan konsentrasi, meningkatkan kewaspadaan, dan memberi kekuatan untuk otak. ${ }^{1}$

Namun, masih banyak anak yang tidak membiasakan sarapan pagi sebelum ke sekolah. Kebiasaan mengabaikan sarapan pagi mengakibatkan tubuh tidak mendapatkan asupan zat gizi yang cukup sehingga menurunkan status gizi dan akhirnya kembali mempengaruhi prestasi belajar anak.

Menurut Kementrian Kesehatan Republik Indonesia, membiasakan sarapan termasuk salah satu dari 10 pesan umum yang terdapat dalam Pedoman Gizi Seimbang (PGS). Pesan ini berlaku untuk masyarakat umum dari berbagai lapisan yang dalam kondisi sehat. ${ }^{2}$ Berdasarkan Riset Kesehatan Dasar (Riskesdas) tahun 2010 menyebutkan bahwa sebanyak 16,9\% - 50\% anak usia sekolah dan remaja, serta rata-rata $31,2 \%$ orang dewasa di Indonesia tidak biasa sarapan. Sebanyak $26,1 \%$ anak sekolah hanya mengonsumsi minuman saat sarapan seperti air putih, susu, atau teh dan $44,6 \%$ mengonsumsi sarapan berkualitas rendah mutu sarapan penduduk Indonesia masih rendah karena masih banyak anak yang tidak terbiasa sarapan sehat. ${ }^{3}$

Penelitian yang dilakukan oleh Hardiansyah dan Aris menyebutkan bahwa dari 35.000 anak usia sekolah sekitar $26,1 \%$ sarapan hanya dengan air minum dan $44,6 \%$ memperoleh asupan energi kurang dari $15 \%$ kebutuhan energi per hari, yang seharusnya 15 - 30\% kebutuhan yang membuktikan masih banyak anak Indonesia $(69,6 \%)$ yang belum mengkonsumsi sarapan dengan anjuran gizi seimbang.4,5 Pada penelitian yang dilakukan Niswah menyebutkan bahwa sarapan memiliki dampak yang positif baik terhadap kewaspadaan, kemampuan kognitif, kualitas belajar maupun performa akademik pada anak dan remaja. Selain itu sarapan juga memberikan dampak positif pada status nutrisi, kebiasaan melewatkan sarapan merupakan salah satu faktor risiko terjadinya overweight, obesitas, serta pola perilaku yang tidak sehat pada anak dan remaja. ${ }^{5,6}$

Persentasi yang tinggi dari kebiasaan melewatkan sarapan dilaporkan terjadi pada usia remaja. Penelitian di Belanda yang dilakukan oleh Vingerhoed menyebutkan bahwa sebanyak 39,7\% remaja usia 12-18 tahun tidak sarapan setiap hari. ${ }^{6}$ Penelitian 
MEDIC, Volume 4, nomor 1, April 2021, Hal:198-205 Riska Marvelia, dkk. Hubungan sarapan...

yang dilakukan Khalida juga menyebutkan bahwa kebiasaan sarapan dapat mempengaruhi fungsi kognitif yang meliputi tingkat konsentrasi, performa belajar dan memori. $^{7}$

Pada penilitian yang dilakukan Umi di SMA N 8 kab. Muaro Jambi didapatkan bahwa remaja mempunyai kebiasaan tidak sarapan lebih besar (60\%) dibandingkan mereka yang sarapan, frekuensi makan $65 \%$ remaja $>=3 \mathrm{kali} / \mathrm{hari}$, mempunyai kebiasaan tidak mengkonsumsi makanan penghambat penyerapan zat besi sebesar $72,2 \%$ lebih besar dari yang mengkonsumsinya, mempunyai kebiasaan konsumsi sumber makanan peningkat serapan zat besi sebesar $70 \%$ lebih besar dari yang tidak konsumsi, mempunyai kebiasaan konsumsi makanan sumber protein baik hewani atau nabati sebesar $72,2 \%$, tidak punya pantangan makanan tertentu sebesar $73,9 \%$ dan tidak melakukan diet tertentu sebesar $87,2 \%$. Berdasarkan penelitian tersebut dapat disimpulkan bahwa masih banyak anak-anak Sekolah Menengah Atas di Jambi yang melewatkan sarapan pagi. ${ }^{8}$

Penelitian ini bertujuan untuk mengetahui hubungan sarapan pagi dengan prestasi belajar siswa di SMA Negeri 4 Kota Jambi Tahun 2020.

\section{METODE}

Penelitian ini telah dilakukan pada bulan Juli - Agustus 2020 di SMA Negeri 4 Kota Jambi. Penelitian ini menggunakan jenis penelitian analitik kuantitatif dengan menggunakan pendekatan potong lintang (cross sectional).
Subjek pada penelitian ini adalah siswa kelas X MIPA dan X IIS SMA Negeri 4 Kota Jambi Tahun 2020. Cara pengambilan sampel dalam penelitian ini adalah dengan cara simple random sampling dan didapatkan sebanyak 110 sampel.

Data primer Sarapan pagi daimbil berdasarkan pengetahuan, sikap dan tindakan diukur dengan menggunakan kuesioner. Prestasi belajar diukur melalui rekapitulasi nilai raport semester siswa. Data sekunder meliputi gambaran umum sekolah yang diperoleh dari dokumen sekolah dan data prestasi belajar siswa yang diperoleh dari rekapitulasi nilai raport. Data yang terkumpul selanjutnya dianalisis dengan analisis univariat untuk memberikan gambaran karakteristik masing-masing variabel yang diteliti dan analisis bivariat untuk membuktikan ada atau tidaknya hubungan antara variabel independen dan dependen dengan menggunakan uji Fisher.

\section{HASIL DAN PEMBAHASAN}

Berdasarkan hasil penelitian mengenai hubungan sarapan pagi dengan prestasi belajar siswa di SMA Negeri 4 Kota Jambi Tahun 2020, didapatkan hasil sebagai berikut. 
MEDIC, Volume 4, nomor 1, April 2021, Hal:198-205 Riska Marvelia, dkk. Hubungan sarapan...

Tabel 1. Distribusi Frekuensi Responden Berdasarkan Sarapan Pagi Siswa di SMA Negeri 4 Kota Jambi Tahun 2020

\begin{tabular}{lcc}
\hline $\begin{array}{l}\text { Sarapan } \\
\text { Pagi }\end{array}$ & $\begin{array}{c}\text { Frekuensi } \\
\mathbf{n}\end{array}$ & $\begin{array}{c}\text { Persentase } \\
\%\end{array}$ \\
\hline Kurang & 33 & 30,0 \\
Cukup & 43 & 39,1 \\
Baik & 34 & 30,9 \\
Total & 110 & 100 \\
\hline
\end{tabular}

Berdasarkan tabel 1 di atas, diperoleh gambaran sarapan pagi siswa di SMA negeri 4 Kota Jambi tahun 2020 menunjukkan bahwa sebanyak 34 responden $(30,9 \%)$ baik, 43 responden $(39,1 \%)$ cukup dan 33 responden $(30,0 \%)$ kurang.

Tabel 2. Distribusi Frekuensi Responden Berdasarkan Prestasi Belajar Siswa di SMA Negeri 4 Kota Jambi Tahun 2020.

\begin{tabular}{|c|c|c|}
\hline $\begin{array}{l}\text { Prestasi } \\
\text { Belajar }\end{array}$ & $\begin{array}{c}\text { Frekuensi } \\
n\end{array}$ & $\begin{array}{c}\text { Persentase } \\
\%\end{array}$ \\
\hline Kurang & 6 & 5,5 \\
\hline Cukup & 45 & 40,9 \\
\hline Baik & 59 & 53,6 \\
\hline Total & 110 & 100 \\
\hline
\end{tabular}

Berdasarkan tabel 2 di atas, diperoleh gambaran prestasi belajar siswa di SMA negeri 4 Kota Jambi tahun 2020 menunjukkan bahwa sebanyak 59 responden $(53,6 \%)$ baik, 45 responden $(40,9 \%)$ cukup dan 6 responden $(5,5 \%)$ kurang.

Tabel 3. Hubungan Antara Sarapan Pagi Dengan Prestasi Belajar Siswa di SMA Negeri 4 Kota Jambi Tahun 2020.

\begin{tabular}{|c|c|c|c|c|}
\hline \multirow{3}{*}{$\begin{array}{l}\text { Sarapan } \\
\text { pagi }\end{array}$} & \multicolumn{3}{|c|}{ Prestasi belajar } & \multirow{3}{*}{$\begin{array}{l}\text { Nilai } \\
\text { p }\end{array}$} \\
\hline & Kurang & Cukup & Baik & \\
\hline & $n(\%)$ & $n(\%)$ & $\mathrm{n}(\%)$ & \\
\hline \multirow[t]{2}{*}{ Kurang } & $3(9,1)$ & 15 & 15 & \multirow{6}{*}{0,014} \\
\hline & & $(45,5)$ & $(45,5)$ & \\
\hline \multirow[t]{2}{*}{ Cukup } & $2(4,7)$ & 23 & 18 & \\
\hline & & $(53,5)$ & $(41,9)$ & \\
\hline \multirow[t]{2}{*}{ Baik } & $1(2,9)$ & 7 & 26 & \\
\hline & & $(20,6)$ & $(76,5)$ & \\
\hline
\end{tabular}

Berdasarkan tabel 3 di atas, diperoleh gambaran bahwa dari 33 responden dengan kebiasaan sarapan pagi kurang sebanyak 3 responden $(9,1 \%)$ memiliki prestasi belajar kurang, 15 responden $(45,5 \%)$ memiliki prestasi belajar cukup dan 15 responden (45,5\%) memiliki prestasi belajar baik. Dari 43 responden dengan kebiasaan sarapan pagi cukup sebanyak 2 responden (4,7\%) memiliki prestasi belajar kurang, 23 responden $(53,5 \%)$ memiliki prestasi belajar cukup dan 18 responden $(41,9 \%)$ memiliki prestasi belajar baik. Sedangkan dari 34 responden dengan kebiasaan sarapan pagi baik sebanyak 1 responden (2,9\%) memiliki prestasi belajar kurang, 7 responden $(20,6 \%)$ memiliki prestasi belajar cukup dan 26 responden $(76,5 \%)$ memiliki prestasi belajar baik. Diperoleh gambaran bahwa terdapat adanya hubungan antara sarapan pagi dengan prestasi belajar siswa di SMA Negeri 4 Kota Jambi tahun 2020, 
MEDIC, Volume 4, nomor 1, April 2021, Hal:198-205 Riska Marvelia, dkk. Hubungan sarapan...

dipergunakan uji analisis Fisher dan terdapat hubungan yang signifikan antara sarapan pagi dengan prestasi belajar siswa dengan $p$-value $0.014(p<0.05)$.

Hasil penelitian gambaran sarapan pagi siswa di SMA Negeri 4 Kota Jambi tahun 2020 didapatkan data bahwa kebiasaan siswa dalam menerapkan sarapan pagi sudah cukup. Namun, masih terdapat siswa yang kurang menerapkan kebiasaan sarapan pagi. Hal tersebut sesuai dengan data yang diperoleh dari Riset Kesehatan Dasar 2010 bahwa 16,9\% - 50\% anak usia sekolah dan remja di Indonesia tidak biasa sarapan pagi. Selain tidak mau sarapan, tidak semua orang menyadari dan mengetahui pentingnya sarapan.

Definisi operasional sarapan yang digunakan dikategorikan cukup yaitu $\geq 4$ kali/ minggu mengandung energi 20\% $25 \%$ dari kebutuhan total harian. Subjek penelitian rata-rata melakukan sarapan lebih dari 4 kali seminggu. Hal ini dapat dikatakan bahwa kualitas makanan yang sudah cukup baik.

Penelitian ini sejalan dengan penelitian yang dilakukan oleh Nurwijayanti (2018) dimana terdapat 8 responden $(14,8 \%)$ dengan sarapan pagi baik, 30 responden $(55,6 \%)$ dengan sarapan pagi cukup dan sebanyak 16 responden (29,6\%) dengan sarapan pagi kurang. Hal ini berbanding lurus dengan penelitian yang dilakukan oleh Firdaus dkk (2019) dimana terdapat sebanyak 44 responden $(40,4 \%)$ memiliki sarapan pagi baik, 65 responden $(59,6 \%)$ memiliki sarapan pagi cukup dan tidak terdapat responden dengan sarapan pagi kurang. ${ }^{9,10}$

Membiasakan sarapan pagi dapat meningkatkan ketahanan fisik, mempertahankan daya tahan tubuh, meningkatkan kondisi fisik agar tetap prima, meningkatkan kebugaran jasmani dan konsentrasi yang dapat memudahkan menyerap informasi. Kebiasaan sarapan pagi juga dapat membantu seseorang untuk memenuhi kecukupan gizinya sehari-hari. Jenis hidangan untuk sarapan pagi dapat dipilih dan disusun sesuai dengan kebutuhan gizi. Seseorang yang tidak sarapan pagi berisiko menderita gangguan kesehatan berupa penurunan kadar gula darah dengan tanda-tanda antara lain: lemah, keluar keringat dingin, kesadaran menurun bahkan pingsan. ${ }^{11}$

Hasil penelitian gambaran prestasi belajar siswa di SMA negeri 4 Kota Jambi tahun 2020 menunjukkan bahwa sebagian besar siswa mendapat prestasi belajar yang baik. Untuk menilai prestasi belajar siswa di SMA Negeri 4 Kota Jambi Tahun 2020, peneliti menggunakan nilai rata-rata raport semester yang digunakan sebagai alat ukur prestasi belajar siswa.

Hal ini sejalan dengan penelitian yang dilakukan oleh Nurdin (2015) didapatkan bahwa sebanyak 46,8\% responden dengan prestasi belajar baik, $41,8 \%$ responden dengan prestasi belajar cukup dan sebanyak $1,3 \%$ responden dengan prestasi belajar kurang. Hal ini berbanding lurus dengan penelitian yang dilaukan oleh Nurwijayanti (2018) didapatkan bahwa sebanyak 5 responden 
MEDIC, Volume 4, nomor 1, April 2021, Hal:198-205 Riska Marvelia, dkk. Hubungan sarapan...

$(9,3 \%)$ dengan prestasi belajar baik, 38 responden $(70,4 \%)$ dengan prestasi belajar cukup dan sebanyak 11 responden $(20,4 \%)$ dengan prestasi belajar kurang. ${ }^{9}$

Perlu diketahui bahwa prestasi belajar siswa tidak semata-mata ditentukan oleh tingkat kemampuan intelektualnya, terdapat juga faktor-faktor lain seperti motivasi, sikap, kesehatan fisik dan mental, kepribadian, ketekunan dan lain- lain yang turut mempengaruhi prestasi belajar. Secara umum banyak faktor yang mempengaruhi Prestasi belajar, dimana sifat-sifat tersebut bersifat alamiah yang tidak bisa dirubah (faktor internal), sedangkan faktor eksternal yang mempengaruhi prestasi belajar (kebiasaan belajar dan status gizi).

Hasil penelitian menggunakan uji analisis Fisher terdapat hubungan yang bermakna antara sarapan pagi dengan prestasi belajar siswa di SMA Negeri 4 Kota Jambi tahun 2020.

Dari hasil penelitian menunjukkan bahwa siswa yang sarapan paginya cukup baik didapatkan hasil prestasi belajar yang cukup baik pula. Dilihat dari frekuensi sarapan pagi yang dilakukan oleh para siswa, semakin besar frekuensi sarapan yang dilakukan dalam seminggu makan prestasi belajar yang dihasilkan juga akan menjadi baik.

Hal ini sejalan dengan penelitian yang dilakukan oleh Nurwijayanti (2018) bahwa terdapat hubungan antara sarapan pagi dengan prestasi belajar siswa SMA Negeri Kota Kediri. Hasil penelitian ini berbanding lurus dengan penelitian yang dilakukan oleh Firdaus dan Rasyidianah
(2019) bahwa terdapat hubungan positif antara kebiasaan sarapan pagi dengan prestasi belajar siswa di SMAN 3 Watansoppeng (nilai sig. 1 tailed $0,000<$ 0,05 dan nilai Pearson Correlation $+0,583) \cdot{ }^{9,10}$

Penelitian ini tidak sejalan dengan penelitian yang dilakukan oleh Noviyanti dkk $^{1}$ (2015) yang menyatakan bahwa tidak terdapat hubungan antara sarapan pagi dengan prestasi belajar siswa dan menyatakan bahwa sarapan pagi bukanlah satu-satunya yang mempengaruhi prestasi belajar. Namun, masih ada faktor lain seperti keluarga, watu belajar (pagi, siang, malam), tempat belajar dan alat-alat yang dipakai untuk belajar yang dapat mempengaruhi prestasi belajar

Hasil penelitian ini menunjukkan bahwa sebagian besar responden sudah mempunyai kebiasaan yang baik yakni dalam hal sarapan pagi. Sarapan pagi memberikan dampak yang baik bagi anak salah satunya memudahkan anak dalam menyerap pelajaran yang diberikan oleh Bapak ibu gurunya. Sesuai dengan Departemen Kesehatan (Depkes) yang menyatakan bahwa makan pagi bagi anak sekolah akan dapat meningkatkan konsentrasi dan memudahkan menyerap pelajaran sehingga meningkatkan konsentrasi belajar.

Di dalam menu sarapan biasanya juga mengandung zat gizi yang dibutuhkan oleh tubuh anak. Sarapan adalah kebutuhan manusia yang dibutuhkan secara teratur setiap pagi, untuk kebutuhan nutrisi dan perkembangan otak bagi anak yang seharusnya dimulai sejak dini. 
Peneliti dapat mengetahui dari kuesioner yang disebarkan berupa google form yang telah diisi oleh responden tentang frekuensi sarapan pagi responden yang dapat mempengaruhi prestasi belajar siswa yang diukur menggunakan nilai ratarata raport semester siswa. Dan peneliti mendapatkan bahwa sebagian responden mempunyai kebiasaan kurang dalam menerapakan kebiasaan sarapan pagi. Beberapa faktor yang menyebabkan anak kurang melakukan sarapan pagi adalah belum tersedianya makanan di rumah (makanan belum matang) sedangkan jam sekolah sudah dimulai dan akhirnya anak mengambil keputusan untuk tidak sarapan dan menunda sarapan sampai dengan istirahat pertama.

Selain itu alasan lain yang disampaikan responden adalah karena tidak terbiasa sarapan terlalu pagi dan sarapan yang terlalu pagi akan menyebabkan perutnya sakit. Responden yang tidak sarapan biasanya makan dijam istirahat atau menyediakan makanan selingan, namun sama saja itu artinya responden sudah melewatkan sarapan.

$$
\text { Kebutuhan energi sangat }
$$

dibutuhkan pada proses pembelajaran anak, karena pada proses belajar ilmu pengetahuan diterima berhubungan dengan jasmani yang diperoleh melalui panca indra, sehingga apabila salah satu panca indra rusak maka anak tidak akan sempurna menerima pelajaran yang berdampak terhadap buruknya hasil belajar mereka. Anak yang tidak sarapan berarti pada pagi harinya tidak mendapatkan asupan nutrisi atau gizi sehingga dapat berdampak buruk bagi kesehatannya selain mengalami hambatan pertumbuhan fisik juga akan mengalami gangguan belajar berupa penurunan prestasi akademik disekolah.

Penelitian ini memiliki beberapa keterbatasan. Penggunaan alat ukur kuesioner sarapan pagi yang berupa hanya dalam frekuensi sarapan. Tambahan lain untuk studi selanjutnya adalah dalam hal menilai sarapan pagi dapat digunakan kuantitas dari menu sarapan itu sendiri dan untuk prestasi belajar sendiri dapat ditambah alat ukur menggunakan nilai harian siswa sehari-hari. Percobaan intervensi diperlukan untuk mengkaji manfaat sarapan pagi terhadap prestasi belajar siswa.

Faktor perancu lain pada penelitian yang tidak dianalisis adalah pengelompokan jenis kelamin dan keterlibatan orang tua dalam proses belajar anak.

\section{KESIMPULAN}

Berdasarkan hasil penelitian dan uraian dalam pembahasan tentang hubungan sarapan pagi dengan prestasi belajar siswa di SMA Negeri 4 Kota Jambi tahun 2020, maka dapat ditarik beberapa kesimpulan, yakni : siswa sudah memiliki kebiasaan sarapan pagi yang cukup, dan siswa juga memiliki prestasi belajar yang baik serta terdapat hubungan antara sarapan pagi dengan prestasi belajar siswa.

Bagi peneliti selanjutnya, diharapkan hasil penelitian ini dapat dijadikan sebagai bahan acuan dan tambahan referensi bagi peneliti 
MEDIC, Volume 4, nomor 1, April 2021, Hal:198-205 Riska Marvelia, dkk. Hubungan sarapan...

selanjutnya yang melakukan penelitian

yang sama tentang hubungan kebiasaan

sarapan pagi dengan prestasi belajar siswa

dengan mengambil tempat yang berbeda

dan variabel penelitian yang berbeda seperti faktor kecukupan gizi sarapan pagi, membandingkan dengan kebiasaan jajan, kualitas dari sarapan pagi, serta variabel lainnya yang belum diteliti dalam penelitian ini.

\section{DAFTAR PUSTAKA}

1. Noviyanti R, Kusudaryati D. Hubungan Kebiasaan Sarapan Pagi Dengan Prestasi Belajar Siswa SD Muhammadiyah Program Khusus Surakarta. 2018;16(1), 72-77.

2. Kementerian Kesehatan RI. Pedoman gizi seimbang. Jakarta. 2014

3. Badan Penelitian dan Pengembangan Kesehatan Kementrian Kesehatan RI, Riset Kesehatan Dasar (Riskesdas) Tahun 2010.

4. Hardinsyah H, Aries M. Jenis Pangan Sarapan Dan Perannya Dalam Asupan Gizi Harian Anak Usia 6-12 Tahun Di Indonesia. J. Gizi Dan Pangan. 2016

5. Niswah I, Damanik, M , Ekawidyani K. Kebiasaan Sarapan, Status Gizi, Dan Kualitas Hidup Remaja Smp Bosowa Bina Insani Bogor. J. Gizi Dan Pangan. 2015;9(1)

6. Vingerhoeds. Breakfast Benefits For Children And Adolescents. Wageningen UR Food \& Biobased Research. 2015;21(2)

7. Khalida E, Fadlyana E, Somasetia H. Hubungan Kebiasaan Sarapan dengan Prestasi Belajar dan Fungsi Kognitif pada Anak Sekolah. 2015;4(1)

8. Kalsum U, Halim R. Kebiasaan Sarapan Pagi berhubungan dengan Kejadian Anemia pada Remaja di SMA Negeri 8 Muaro Jambi. Jurnal penelitian universitas jambi seri sains. 2016;18(1), 9-19

9. Nurwijayanti, N. Pola Makan, Kebiasaan Sarapan dan Status Gizi Berhubungan Dengan Prestasi Belajar Siswa SMK di Kota Kediri. Care: Jurnal IImiah IImu Kesehatan. 2018. 6(1), 54-63.

10. Firdaus $F$ \& Rasydianah R. Hubungan Sarapan Pagi dengan Prestasi Belajar Siswa di SMA Negeri 3 Watansopeng. 2019 1(1), 33-40.

11. Hartanti, T. S. Hubungan Antara Kebiasaan Sarapan Pagi Dan Asupan Zat Gizi Makro (Energi Dan Protein). 20182 (1). 